\title{
A Rapid Assessment of Key COVID-19 Themes in African American YouTube Religious Sermons
}

\author{
Cheryl A Armstead ${ }^{1,3 *}$, Godwin Mbamalu ${ }^{2,3}$ and James R Hebert ${ }^{3}$ \\ ${ }^{1}$ Department of Psychology, College of Arts and Sciences, University of South Carolina, USA \\ ${ }^{2}$ Benedict College Office of Research, USA \\ ${ }^{3}$ Department of Epidemiology and Biostatistics and Cancer Prevention and Control Program, Arnold School of Public Health, University of South Carolina, USA
}

*Corresponding author: Cheryl Annette Armstead, Associate Professor, Department of Psychology, University of South Carolina, 1512 Pendleton Street, Columbia, SC 29208, USA.
Received Date: May 04, 2020

Published Date: June 16, 2020

\begin{abstract}
Background: As social distancing became a pervasive public health necessity during COVID-19 pandemic during the Spring of 2020, the exponential use of digital technology impacted the worldview and health behavior context of African American churches in unknown ways. Digital sermons may be among the most effective and necessary ways of reaching African American congregations regarding behavioral and cognitive strategies to remain healthy during the age of COVID-19. Our purpose was to conduct a rapid thematic assessment of digital sermon key content and to identify health promotion and content representing barriers to health embedded in digital sermons during the initial social distancing period of the COVID-19 pandemic between March and April 2020.
\end{abstract}

Methods: Our qualitative study of 17 randomly selected sermons indicates that digital church communication creates a viable messaging platform for churches during social distancing.

Results: Four main themes were identified in the sermons: (a) clarifying COVID-19 church health policies, (b) disconnectedness and reconnection (c) biblically based resilience and health self-agency, and (d) faith, fear, and health.

Conclusion: We discuss implications for future social marketing interventions in churches through enhanced support for digital sermon delivery as a valuable health messaging platform for African American faith communities.

Keywords: COVID-19, African Americans, Religion, Rapid qualitative analysis, Digital sermons, Health behavior

Abbreviations: SC: South Carolina; COVID-19: Corona Virus

\section{Background}

Asymptomatic infection with SARS-CoV-2, the virus that causes novel COVID-19, disproportionately affects African Americans through little understood biobehavioral, age-related, systematic sociocultural vulnerabilities, and adverse outcomes associated with pre-existing co-morbid conditions in South Carolina (SC) [1,2]. African Americans represent 27.1\% of the SC's population but include $52 \%$ of COVID-19 deaths [3]. The sociocultural determinants of these health disparities are not well-understood in this population. As a response to a deadly upswing of pastoral and congregational deaths during late April 2020 [4], a majority of African American churches in the Southern United States continue to practice worship-at-home methods of social distancing and infection mitigation education through virtual worship practices [5]. Church services, funerals, Bible studies, and other traditional religious events continue to be shifted from in-person congregational spaces to streaming services like Zoom, Skype, or Facebook Live from March to May 2020.

The importance of faith and the church in the health status of African Americans in America is unquestioned. Church has not only been a place of worship but a refuge in times of trouble, including 
health advocacy, education, and sometimes inaccurate health messaging. SC is described as, "The Buckle of the Black Bible Belt" due to its dense concentration of churches state-wide and evergrowing faith congregations. Ethnic disparities among COVID-19 cases and deaths adversely impact the Black faith community [3]. The two most prevalent denominations in South Carolina are Missionary Baptists and African American Episcopal faith communities. In SC, the African American church has historically served as a transformative institution for health and social activism promoting a message of equality, collectivism, and organizational self- determination [6].

During the COVID-19 pandemic, the power of digital AfricanAmerican faith health messaging has yet to be acknowledged as a promising venue for enhancing infection prevention and screening/ contact tracing efforts, telehealth messaging [7-9], and improving the likelihood of future vaccine acceptability. There is a dire need to conduct a rapid thematic assessment of psychosocial, public health, and spiritual messaging from pastors during the peak of the pandemic, that may affect health behaviors, antibody testing, and later vaccine uptake among African Americans [10].

Digital sermons posted by pastoral leaders, as social influencers, establish an innovative avenue to address psychosocial risk factors and community vulnerability during the COVID-19 pandemic. African-American homiletic preaching philosophy suggests that, "Effective preaching is a transaction between preacher and congregation who comes to trust the preacher and thereby accepts the preacher's message" because it reflects authenticity to one's cultural self but also a sensitivity to the ways listeners from one context to another hear and process sermons [11]. The stages and structure African American preaching homiletics are comparable to cognitive-behavioral paradigms used in health promotion [12]. Public health messaging and preaching homiletics go hand in hand.

The purpose of this rapid qualitative assessment was to understand how video sermons are utilized among AfricanAmerican ministers to informally set the stage for a faith-based discourse that includes COVID-19 messaging within a cultural homiletic praxis during the peak period of the pandemic [11]. Because this is a rapid qualitative research study about a previously unexplored health concern in the Black community, a single research question guided the current qualitative research. In this formative study we ask, "What themes undergird key mental and physical health messages in YouTube sermons delivered to AfricanAmerican southern congregants during the initial stages COVID-19 pandemic?"

\section{Method}

\section{Coding}

A codebook with definitions was used to categorize the topics of the messages, the type of media vehicle of which the messages were part, and the source of that media vehicle. Both deductive and inductive methods were used to establish the categories within the codebook. A review of the literature, as well as immersion in YouTube-delivered church sermons, was used to inform the development of a primary list of key health behavior categories and codes. Once both inductive and deductive codes were established, the codebook was reviewed by researchers with the larger study and experts in faith-based health promotion to ensure definitions were grounded in the field [13-16].

\section{Sermon selection and data collection}

There are hundreds of Black church sermons videos posted on YouTube [15]. The researchers wished to rapidly identify the contextual and experiential meanings of pastoral sermon messaging during the COVID-19 pandemic among Black churches. This formative study was not structured to identify sermon themes before the crisis or to produce a generalizability at the expense of depth. Fifty random digital sermons were selected from South Carolina YouTube postings. We randomly selected YouTube sermons using a lexical search by keyword combinations of the following: a) South Carolina Black church, b) African American, sermon, c) Missionary Baptist, d) African Methodist Episcopal, which were posted between March 20th and April 20th. These sermons were then purposively chosen based on the availability of YouTube automatic transcripts with time stamps, and a viewership of greater than 30 . For each of the resulting sermons, we selected the most highly viewed sermon within the time span. Therefore, 20 sermon videos that met initial criteria to be to be included in this study. Secondary examination of the sermons was logistical and examined data viability. Our final sample contained 17 sermons that met our initial selection criteria, had sufficient sound quality, transcripts, and had sufficiently long duration to analyze for thematic content.

\section{Data analysis}

Before initiating the data analysis process, we organized the data using NVivo 12 Qualitative Data Analysis Software (QSR 2020) [14]. The NVivo program allowed us to embed the videos with field note and codes. We analyzed the YouTube generated transcripts and timestamps within the videos to assist with the coding process. This system of digital data analysis allowed us to easily refer to specific data components. Specifically, we utilized qualitative video data analysis techniques to understand how video sermons assist with COVID-19 messaging among seventeen randomly selected YouTube.com streaming church services and posted sermons.

Open coding was performed to allow grounded themes to emerge from the data. As a rapid communication preliminary study, coding was performed by the principal investigator without interrater reliability assessment. Axial coding was guided by the aims of the research and review of the literature. Codes were combined and major themes and subthemes were examined in more depth. Selective coding was used to focus the final analysis and to compare themes related to COVID-19 messaging across sermons. 
To ensure findings were credible, several steps were taken. These included community-based debriefing, member checks, consultation with the larger study team as well as with coauthors throughout data collection. This study was approved by our university's Institutional Review Board. Pastoral and church consent forms were not required, as all the videos and associated comments are considered public domain. Furthermore, we did not have to acquire permission from YouTube.com to analyze these videos because this study did not involve the modification, replication, or recycling of any of the analyzed video. We took a systematic approach of analysis to interpret the videos and associated commentary that already existed.

\section{Results}

As a result of inductive data analysis, prevailing themes emerged reflective of how video and streaming church services are capable as influencing public health pedagogy in the African American faithcommunity during the peak of the April 2020, COVID-19 pandemic. Key primary themes suggest that these sermons are important venues for public health pedagogy, psychosocial well-being, and virtual places of hope among African American faith communities. Four important underlying sub- themes were identified in the sermons: (a) clarifying COVID-19 church health policies, (b) disconnectedness and reconnection (c) biblically based resilience and health self-agency, (d) faith, fear, and health.

\section{Clarifying COVID-19 church policies}

Sixty-seven percent of sermons, pastors applied Leviticus chapter thirteen's Biblical and cultural codes of health behavior associated with leprosy to clarify contemporary COVID-19 social distancing practices [17-19]. Leviticus 13:45-46 focuses on stopping the proliferation of a disease through behavior, culture, and religious directives or mores. Sermon narratives containing informal church policies as key themes were present in nearly $80 \%$ of the sermons but did not reflect codified church mandates for sheltering in place, handwashing, or face mask protection in public interactions outside of the church Humor was used to address reify informal policies.

\section{Disconnectedness \& reconnection}

Pastor's themes in the sermons included their own feelings of disconnection due to inexperience or lack of comfort using digital sermons. Eight percent of sermons targeted mental health issues that may be associated with social isolation and physical disconnectedness with the congregation. For example, one pastor addressed a sermon narrative focusing on the spiritual experience of multi-dimensional fellowship across sermon delivery modalities. He preached, "People should be shouting and praising the Lord in their homes, but I too need to feel your spirit over the web."

\section{Biblical resilience and health self-agency}

Admonitions to increase individual and church health selfagency were repeated themes embedded in $29 \%$ of sermons. Pastors preached that Jesus turned his human instincts of self-preservation into self-sacrifice in times of uncertainly and fear. One pastor's sermon eloquently addressed the notion of the "new normal. He delivered a sermon focusing on the following key narratives regarding "psychosocial normalcy" in the Biblical scripture and during our contemporary pandemic: "The coronavirus has been knocking some of us down and knocking some of us out! But if you think about it for a moment, the sacrifices we must make to put us in a better position to understand how the disciples must have felt on Easter. Easter was never meant to go back to normal; but was, and still is, intended to make all things new through sacrifice for each other."

\section{Faith, fear, and health}

A small, but important portion of the sermons addressed themes consisting of narratives about prophetic health plagues and signs of the end times. Fear induction messaging may be the outcome of these themes, but we must also consider them as fear reducers for many African Americans seeking an end to inequities and tribulations in this world. Sin and rebelliousness were thematically integrated into four percent of the sermons as contributing factors for risky heath behavior and COVID-19 infection. Representative of this prophetic homiletic theme is the statement of a rural Baptist pastor, "The prophecies the Book of Revelations 9:12 are upon us: The first disaster is past. There are still two woes coming after this."

Despite apocalyptic narratives, many sermons contained fearreduction themes and predominated many of the sermons in the context of other parts of the sermon. Fifty-eight percent of sermons in the sample referred to fear reduction themes in 2 Timothy 1:7, "for God gave us a spirit not of fear but of power and love and selfcontrol." A pastor exemplified this theme in his sermon, "I believe the Corona [virus] is worse than what we are being told. God has led me to know that if the body of Christ just makes a big change, we will be ok."

\section{Discussion}

Researcher must make use of innovative methodologies during the current pandemic to develop social marketing, telehealth, and intervention tools to reach African Americans, who are the most vulnerable populations across regions, socioeconomic status, and religious denominations. Digital sermons create a valuable and over-looked behavioral and public health risk mitigation platform for churches themes identified in this rapid assessment and formative research.

The results of the study suggest that these sermons are important venues for public health pedagogy, psychosocial wellbeing, and virtual places of hope among African American faith communities. COVID-19 infection mitigation strategies targeting African-American pastor's sermons may be highly efficacious and complementary to social engineering and cognitive-behavioral change in risk profiles. Prevention scientists should consider the 
reach and impact of digitally imprinted social distancing norms on pastor's health-related messages in their digital sermons. Central themes encompassed spiritual wellness, psychological resilience, and a small degree of COVID-19 infection mitigation messaging (e.g., hand washing, social distancing) in the context of traditional Biblical teachings. Prophetic themes were infrequent, but narratives potent in the messaging.

There are methodological issues that must be addressed in later studies including generalizability, various social media platforms attract different audiences. We only used YouTube. com sermons, for consistency, sample selection, deep thematic structure, its transcription platform, and diverse types of congregations and pastoral demographics. Given the nature of qualitative design of the current investigation, we were not able to determine generalizability of our findings even with attempts to randomly select individual sermons across the YouTube posted communications. Also, given the possibility that these findings may not generalize to a national sample of African American pastoral sermons, future studies should explore viewership indicators, regional variations, and a wider array of sermon delivery platforms (e.g. Zoom, YouTube, Twitter, Facebook, live streaming). Analysis of pastoral and church demographic characteristics (e.g. age; SES) may further reveal latent themes in specific COVID-19 messaging and indicators for enhancing antibody testing and COVID-19 vaccine acceptability $[9,20]$.

\section{Conclusion}

Our rapid assessment has implications for public health research and clinical psychology practice with African American faith community during a tragic and possible extended viral pandemic. We promptly identified key themes for future social marketing interventions in churches by digital sermon delivery on YouTube.com as a valuable health messaging platform for African American faith communities. Future research will expand the methodology and research goals of this rapid analysis framework to social media feeds beyond YouTube.com, search for themes in voluntary viewer comments for each sermon, assess viewing patterns and metrics, and document the demographic background of churches that provide online digital sermons. Antibody testing and vaccine acceptability in sermon themes will be examined in detail across the time trajectory of this pandemic by this group of investigators It is our hope that this rapid assessment serves as a formative foundation for COVID-19 messaging intervention development and health dissemination in the African-American churches and other faith communities [9].

\section{Acknowledgement}

The authors wish to gratefully acknowledge the contributions of South Carolina's faith-based community pastors. YouTube access and delivery of their sermons during the COVID-19 pandemic is important both to faith communities and scholarly advancements to decrease the deleterious impacts of COVID-19 in the future.

\section{Conflict of Interest}

Drs. Cheryl A. Armstead, Godwin I. Mbamalu, and James R. Hebert certify that they have no affiliations with or involvement in any organization or entity with any financial interest (such as honoraria; educational grants; participation in speakers' bureaus; membership, employment, consultancies, stock ownership, or other equity interest; and expert testimony or patent-licensing arrangements), or non-financial interest (such as personal or professional relationships, affiliations, knowledge or beliefs) in the subject matter or materials discussed in this manuscript.

\section{References}

1. Morawska L, Cao J (2020) Airborne transmission of SARS-CoV-2: The world should face the reality. Environ Int 139: 105730.

2. Yancy CW (2020) COVID-19 and African Americans. JAMA.

3. (2020) Department of Health and Environmental Control SC. SC Demographic Data (COVID-19).

4. Boorstein M (2020) Virus kills up to 30 leaders in largest black U.S. Pentecostal denomination. Washington Post, USA.

5. Wright S (2020) As Southern States Reopen, African American Lives are Still Hanging in the Balance Most States Scratch Stay-At-Home Orders Despite Experts' Warnings. Washington Informer Newspaper.

6. Hébert JR, Braun KL, Kaholokula JK, Armstead CA, Burch JB, et al. (2015) Considering the Role of Stress in Populations of High-Risk, Underserved Community Networks Program Centers. Prog Community Health Partnersh 2015(9 Suppl): 71-82.

7. Myers US, Birks A, Grubaugh AL, Axon RN (2020) Flattening the Curve by Getting Ahead of It: How the VA Healthcare System Is Leveraging Telehealth to Provide Continued Access to Care for Rural Veterans. J Rural Health.

8. Vaccaro AR, Getz CL, Cohen BE, Cole BJ, Donnally CJ (2020) Practice Management During the COVID-19 Pandemic. J Am Acad Orthop Surg 28(11): 464-470.

9. McCall T, Bolton I CS, McCall R, Khairat S (2019) The Use of Culturally Tailored Telehealth Interventions in Managing Anxiety and Depression in African American Adults: A Systematic Review. Stud Health Technol Inform 264: 1728-1729.

10. Wang Z, Tang K (2020) Combating COVID-19: health equity matters. Nat Med 26(4): 458

11. Gilbert K (2011) The Journey \& Promise of African American Preaching. Augsburg Fortress Publishers, Minnesota, USA.

12. Cone JH (2010) A Black Theology of Liberation (40th anniversary edn). Orbis Books, New York, USA.

13. Adu P (2019) A step-by-step guide to qualitative data coding. Routledge, New York, USA.

14. Jackson K (2019) Qualitative data analysis with NVivo. In: Thousand Oaks (Ed), ( $3^{\text {rd }}$ edn), SAGE Publications, CA, USA.

15. Hai-Jew S (2017) Social media data extraction and content analysis. IGI Global, Disseminator of Knowledge, PA, USA.

16. Bazeley P (2013) Qualitative data analysis with NVIVO. In: Thousand Oaks (Ed), ( $2^{\text {nd }}$ edn), Sage Publications, CA, USA.

17. Güner HR, Hasanoğlu I, Aktaş F (2020) COVID-19: Prevention and control measures in community. Turk J Med Sci 50(SI-1): 571-577. 
18. Kissler SM, Tedijanto C, Goldstein E, Grad YH, Lipsitch M (2020) Projecting the transmission dynamics of SARS-CoV-2 through the postpandemic period. Science 368(6493): 860-868.

19. Lippi G, Henry BM, Bovo C, Sanchis-Gomar F (2020) Health risks and potential remedies during prolonged lockdowns for coronavirus disease 2019 (COVID-19). Diagnosis (Berl) 7(2): 85-90.
20. Berg EA, Picoraro JA, Miller SD, Srinath A, Franciosi JP, et al. (2020) COVID-19 - A Guide to Rapid Implementation of Telehealth Services: A Playbook for the Pediatric Gastroenterologist. J Pediatr Gastroenterol Nutr. 